\title{
Peran Komisaris Independen, Ukuran Perusahaan, Kinerja Keuangan dan Leverage Terhadap Usaha Penghindaran Pajak
}

\author{
Yunita Valentina Kusufiyah ${ }^{1}$ \\ Dina Anggraini ${ }^{2}$ \\ ${ }^{1,2}$ Fakultas Ekonomi dan Bisnis Universitas Dharma Andalas (Unidha), Padang, \\ Indonesia \\ e-mail : yunitavalentina@unidha.ac.id
}

\begin{abstract}
ABSTRAK
Proses penagihan pajak menjadi sangat penting dikarenakan pajak memberikan kontribusi yang besar pada pendapatan negara. Hal ini terlihat pada tahun 2017 pajak menyumbangkan sebanyak Rp 1.472,7 triliun dari pendapatan negara. Penelitian ini bertujuan untuk menguji secara empiris pengaruh Komisaris Independen, Ukuran Perusaan, Return On Asset dan Debt to Equity Ratio terhadap penghindaran pajak. Penelitian ini dilakukan pada Bursa Efek Indonesia dengan sektor manufaktur selama tahun 2013-2017. Populasi dalam penelitian ini terdapat 41 perusahaan dengan jumlah observasi 205 yang diperoleh dengan menggunakan metode purposive sampling. Penelitian ini menggunakan teknik analisis data regresi linier berganda dengan hasil penelitian menunjukkan bahwa komisaris independen dan Debt to Equity Ratio tidak memiliki pengaruh signifikan terhadap praktik penghindaran pajak, sementara ukuran perusahaan dan Return On Asset memiliki pengaruh negatif dan signifikan terhadap praktik penghindaran pajak.
\end{abstract}

Kata kunci : Komisaris Independen, ukuran perusahaan, Return On Asset, Debt to Equity Ratio, penghindaran pajak

\begin{abstract}
The process of collecting taxes becomes very important because taxes provide a large contribution to state revenues. This can be seen in 2017 taxes contributed as much as Rp 1,472.7 trillion from state revenues. This study aims to empirically examine the influence of Independent Commissioners, Size, Return On Asset and Debt to Equity Ratio on tax avoidance. This research was conducted on the Indonesia Stock Exchange with the manufacturing sector during 2013-2017. The population in this study were 41 companies with the number of observations 205 obtained using the purposive sampling method. This study uses multiple linear regression data analysis techniques with the results of the study show that independent commissioners and Debt to Equity Ratio do not have a significant influence on tax avoidance practices, while company size and Return On Asset have a negative and significant effect on tax avoidance practices

Keywords : Independent Commissioner, Size, Return On Asset, Debt to Equity Ratio, Tax Avoidance
\end{abstract}

\section{PENDAHULUAN}

Pembangunan negara tidak akan tercapai apabila negara tidak memiliki sumber pendapatan yang besar. Sumber pendapatan negara yang paling besar diperoleh dari pemerimaan pajak. Hal ini terbukti dari data yang disajikan oleh BPS tahun 
2018 (BPS, 2018) bahwa penerimaan negara dari pajak tahun 2017 sebanyak Rp 1.472,7 triliun. Tidak hanya itu pendapatan pajak juga bertambah dari tahun ke tahun. Pada tahun 2013 penerimaan pajak sebanyak Rp 1.077,3 triliyun dan sampai dengan tahun 2017 penerimaan negara pencapai $\mathrm{Rp} 1.472,7$ triliun peningkatan ini setara dengan 73,15 persen. Hal ini menunjukkan bahwa pajak merupakan tulang punggung penerimaan negara. Pajak merupakan peralihan kekayaan dari wajib pajak kepada negara. Dengan adanya perlalihan kekayaan dari wajib pajak kepada negara menjadikan wajib pajak secara alamiah akan melakukan pengurangan beban pajak yang mereka pikul. Ini dikarenakan pajak merupakan beban yang wajib dibayar oleh perusahaan (wajib pajak badan) sehingga dapat berdampak pada penurunan laba bersih selama satu periode. Kondisi ini menjadikan penagihan pajak merupakan hal yang sangat penting. Dalam proses penagihan pajak peran aktif dan kesadaran masyarakat sangat diperlukan. Hanya saja tidak jarang wajib pajak melakukan perlawanan pajak. Apakah itu perlawanan aktif atau perlawanan pasif. Menurut (Suandy, 2014) perlawan pajak pasif merupakan perlawanan yang dilakukan oleh wajib pajak yang berkaitan erat dengan keadaan sosial ekonomi masyarakat negara yang bersangkutan. Pada umumnya masyarakat tidak melakukan suatu upaya yang sistematis dalam rangka menghambat penerimaan negara, tetapi lebih dikarenakan oleh kebiasaan-kebiasaan yang berlaku dalam masyarakat tersebut. Sementara perlawanan aktif merupakan serangkaian usaha yang dilakukan oleh wajib pajak untuk tidak membayar atau mengurangi jumlah pajak yang seharusnya dibayar. Adanya perbedaan kepentigan antara negara dan perusahaan sebagai wajib pajak 
menyebabkan perusahaan melakukan pengurangan beban pajak baik secara legal yaitu dengan penghindaran pajak (tax avoidance) atau pun secara tidak legal yaitu penggelapan pajak (tax evasion). Keduanya ini merupakan perlawanan pajak secara aktif. Penghindaran pajak merupakan tindakan pengurangan pajak secara legal yang dilakukan dengan cara memanfaatkan kelemahan-kelemahan terhadap peraturan perpajakan (Suandy, 2014). Meskipun tindakan penghindaran pajak legal tetapi tindakan ini tidak disukai oleh pemerintah karena akan dapat mengurangi jumlah penerimaan pajak oleh negara (Putri \& Putra, 2017). Salah satu kasus penghindaran pajak yang dilakukan oleh perusahaan manufaktur adalah kasus PT. Cola-Cola Indonesia yang telah merugikan negara senilai Rp 49,24 miliar. Nilai ini diperoleh dari hasil kurang bayar pajak selama tahun 2002-2006. Pengurangan pajak dilakukan oleh perusahaan dengan cara melakukan pembengkakan biaya senilai Rp 566,84 miliar yang menyebabkan penghasilan kena pajak berkurang, sehingga setoran pajaknya pun mengecil (Mustami, 2014). Banyak faktor-faktor yang memotivasi praktik penghindaran pajak yang dilakukan oleh perusahaan seperti : Good Corporate Governance, ukuran perusahaan, kinerja keuangan dan leverage. Agar dapat mencegah terjadinya usaha penghindaran pajak oleh perusahaan maka dibutuhkan tata kelola perusahaan secara baik, hal ini dikenal dengan Good Corporate Governance. Salah satu karakteristik Good Corporate Governance adalah komisaris independen. Komisaris independen merupakan dewan komisaris yang tidak memiliki hubungan terafiliasi baik dengan pemegang saham pengendali, direktur maupun komisaris lainnya (Efffendi, 2016). Komisaris independen berfungsi 
sebagai pelindung kepentingan pemegang saham minoritas dan pemangku kepentingan lainnya serta menjaga prinsip kesetaraan (fairness). Keberadaan Dewan Komisaris Independen diharapkan dapat membantu perusahaan untuk mengalokasikan sumber daya dalam menyusun strategi manajemen pajak yang baik dan memberikan pengalaman serta pengetahuan yang berguna dalam melakukan perencanaan pajak (Sartori, 2008). Proporsi dewan komisaris memiliki peran dalam meningkatkan pengawasan sehingga pihak manajemen menjadi lebih bertindak waspada dalam menjalankan operasional perusahaannya sehingga penghindaran pajak dapat diminimalkan. Berdasarkan penelitian terdahulu mengenai pengaruh faktor-faktor penghindaran pajak masih terdapat ketidak konsistenan hasil penelitian. Hal ini dibuktikan oleh beberapa hasil studi sebelumnya yang menemukan bahwa keberadaan dewan komisaris independen memiliki pengaruh negatif dan signifikan terhadap tindakan penghindaran pajak. Hasil ini menggambarkan bahwa semakin besar proporsi jumlah dewan komisaris independen maka akan semakin efektif pencegahan praktik penghindaran pajak yang dilakukan oleh perusahaan (Prakosa, 2014a). Hal yang sama ditemukan dari hasil penelitian yang dilakukan oleh (Raharjo \& Daljono, 2014) dimana proporsi dewan komisaris akan memberikan pengawasan yang ketat sehingga mampu meminimalkan kesempatan melakukan kecurangan dari manajemen perusahaan. Namun hasil penelitian yang berbeda ditunjukkan oleh hasil penelitian (Ginting, 2016) dimana proporsi dewan komisaris tidak berpengaruh terhadap penghindaran pajak. 
Faktor berikutnya setelah proporsi dewan komisaris independen yang mempengaruhi praktek penghindaran pajak adalah ukuran perusahaan. Perusahaan yang berskala besar akan mempunyai sumber daya melimpah yang dapat digunakan untuk tujuan-tujuan tertentu. Salah satunya adalah untuk tujuan mengurangi beban pajak yang ditanggung oleh perusahaan. Hal ini sesuai dengan hasil studi yang dilakukan oleh (Waluyo, Basri, \& Riau, 2015) bahwa adanya pengaruh yang positif dan signifikan antara ukuran perusahaan dan praktik penghindaran pajak, hal ini dikarenakan perusahaan yang besar memiliki staf ahli yang lebih banyak sehingga perusahaan akan cendrung melakukan praktek penghindaran pajak untuk menjaga laba bersih mereka. Hal ini sejalan dengan penelitian yang dilakukan oleh (Puspita \& Febrianti, 2010), dimana hasil studinya mempertegas bahwa semakin besar perusahaan maka perusahaan tersebut akan lebih berani untuk melakukan pinjaman yang besar sehingga akan menaikkan beban bunga dan berdampak pada rendahnya pendapatan kena pajak. Sementara padangan yang berbeda disajikan oleh (Rusydi, 2013) dalam hasil penelitiannya menyatakan bahwa ukuran perusahaan tidak memiliki pengaruh terhadap dilakukannya praktik penghindaran pajak. Hal ini disebabkan masih lemahnya pengawasan yang dilakukan oleh fiskus sehingga praktik penghindaran pajak menyebar keseluruh ukuran perusahaan. Dalam penelitian ini ukuran perusahaan menggunakan proksi logaritma total asset. Proksi ini dipilih karena memiliki tingkat kesetabilan yang lebih dibandingkan proksi yang lain, dan proksi ini cendrung berkesinambungan antar periode (Hartono, 2013). 
Faktor setelah ukuran perusahaan yang dapat memicu perusahaan melakukan penghindaran pajak adalah kinerja keuangan. Dalam penelitian ini kinerja keuangan diukur dengan menggunakan rasio profitabilitas yaitu Return On Asset (ROA). Rasio Profitabilitas merupakan kemampuan perusahaan dalam memperoleh laba, penelitian yang dilakukan (Utami 2013) membuktikan bahwa perusahaan dengan profitabilitas yang tinggi akan semakin mengungkapkan kewajiban pajaknya. Return On Asset (ROA) merupakan alat analisis yang dapat digunakan untuk mengukur efesiensi penggunaan modal yang bekerja, efesiensi produksi dan efesien bagian penjualan. Return On Asset (ROA) memiliki keterkaitan dengan laba bersih perusahaan dan pengenaan pajak penghasilan untuk perusahaan (Kurniasih \& Sari, 2013). Menurut (Fernández-Rodríguez \& Martínez-Arias, 2012) profitabilitas merupakan salah satu faktor penentu beban pajak, karena perusahaan yang memiliki keuntungan yang besar akan membayar pajak setiap tahun. Sedangkan perusahaan yang memiliki keuntungan yang rendah atau mengalami kerugian akan membayar pajak yang lebih sedikit atau tidak sama sekali. Hasil studi yang sama dibenarkan oleh (Derashid \& Zhang, 2003) bahwa tingkat profitabilitas perusahaan berpengaruh negatif dengan tarif pajak efektif karena semakin efisien perusahaan, maka perusahaan akan membayar pajak yang lebih sedikit sehingga tarif pajak efektif perusahaan tersebut menjadi lebih rendah. Tingginya profitabilitas perusahaan berdampak pada dilakukan perencanaan pajak yang matang sehingga menghasilkan pajak yang optimal, sehingga kecenderungan melakukan penghindaran pajak akan menurun (Hanum \& Zulaikha, 2013). Rasio Keuangan lain yang menjadi faktor pemicu dilakukannya penghindaran pajak 
adalah kemampuan perusahaan dalam menulasi hutang-hutangnya. Hal ini tergambar pada rasio leverage. Leverage merupakan tingkat hutang yang digunakan perusahaan dalam melakukan pembiayaan. Dalam kaitannya dengan pajak, apabila perusahaan memiliki kewajiban pajak tinggi maka perusahaan akan memiliki utang yang tinggi pula. Oleh sebab itu perusahaan akan berusaha melakukan penghindaran pajak. Pengukuran leverage adalah dengan menggunakan persentase dari total hutang terhadap ekuitas perusahaan pada suatu periode yang disebut juga Debt to Equity Ratio (DER). Debt to Equity Ratio (DER) adalah rasio yang membandingkan jumlah Hutang terhadap ekuitas. Rasio ini sering digunakan para peneliti dan para investor untuk melihat seberapa besar hutang perusahaan jika dibandingkan ekuitas yang dimiliki oleh perusahaan atau para pemegang saham. Semakin tinggi angka DER maka diasumsikan perusahaan memiliki resiko yang semakin tinggi terhadap likuiditas perusahaannya. Hal ini sesuai dengan hasil penelitian yang dilakukan oleh (Ozkan \& Ozkan, 2004) memberikan bukti bahwa perusahaan yang memiliki kewajiban pajak tinggi akan memilih untuk berutang agar mengurangi pajak. Penelitian ini memfokuskan sampel penelitian pada salah satu sektor yang terdaftar di Bursa Efek Indonesia selama periode 2013-2017. Pemilihan sampel ini dikarenakan sektor manufaktur memiliki jumlah perusahaan yang lebih banyak dari pada sektor yang lain (Nugraha \& Putu Ery Setiawan, 2019) .

Keberadaan dewan komisaris dalam suatu perusahaan mempunyai tugas utama untuk melakukan pengawasan atas kebijakan pengurusan perusahaan, jalannya pengurusan pada umumnya baik mengenai perusahaan maupun usaha 
perusahaan, dan memberikan nasehat kepada direksi demi kepentingan perusahaan. Selanjutnya, tugas dan kewenangan pengawasan yang dipercayakan kepada dewan komisaris demi kepentingan perusahaan bukan kepentingan satu atau beberapa pemegang saham (Lukviarman, 2016). Hal ini diperkuat melalui surat edaran kepada semua bank umum konvensional di Indonesia No. 15/15/DPNP tanggal 29 April 2013 mengenai pelaksanaan Good Corporate Governance bagi bank umum pada bagian I umum, butir F antara lain disebutkan bahwa dalam pelaksanaan Good Corporate Governance diperlukan keberadaan komisaris independen untuk menghindari konflik kepentingan dalam melaksanakan tugas seluruh tingkatan atau jenjang organisasi bank, keseimbangan (check and balance) serta melindungi kepentingan pemanggu kepentingan khususnya pemilik dana dan pemegang saham minoritas. Untuk independensi dalam pelaksanaan tugas dimaksud, perlu pengaturan mengenai masa tunggu (cooling off) bagi pihak yang akan menjadi pihak independen. Surat edaran tersebut juga mengatur mengenai komisaris indepen yang ditetapkan paling kurang 50 persen dari jumlah anggota dewan komisaris. Komisaris independen adalah anggota dewan komisaris yang tidak memiliki hubungan keuangan, hubungan kepengurusan, hubungan kepemilikan saham, dan atau hubungan keluarga dengan anggota dewan komisaris lainnya, direksi dan atau pemegang saham pengendali atau hubungan dengan bank, yang dapat mempengaruhi kemampuannya untuk bertindak independen (Efffendi, 2016). Kehadiran komisaris independen dalam dewan komisaris mampu meningkatkan pengawasan kinerja direksi. Dimana dengan semakin banyak komisaris independen maka 
pengawasan manajemen akan semakin ketat. Manajemen kerap kali bersifat oportunistik dimana mereka memiliki motif untuk memaksimalkan laba bersih agar meningkatkan bonus. Hal ini sesuai dengan teori keagenan dimana pihak manajemen sebagai agen memiliki informasi yang banyak mengenai kapasitas perusahaan dan perusahaan secara keseluruhan sementara investor sebagai prinsipal tidak tidak memiliki informasi yang cukup tentang itu, untuk itu dewan komisaris independen merupakan perwakilan dari prinsipal yang berperan sebagai pengawas terhadap agen (pihak manajemen perusahaan). Pengawasan yang dilakukan oleh pihak prinsipal terhadap agen akan merupakan strategi bagi prinsipal guna untuk memberikan pengaruh dan pengawasan terhadap manajemen perusahaan (agen) sehingga pihak manajemen (agen) dapat bertindak untuk kepetingan prinsipal serta memberikan keuntungan bagi prinsipal. Laba selama ini dijadikan indikator utama keberhasilan manajer. Salah satu cara meningkatkan laba bersih adalah dengan mengurangi biaya-biaya termasuk pajak dengan begitu manajemen akan berusaha untuk meminimalkan pajak yang harus dibayarkan. Untuk kehadiran dewan komisaris indepen diharapkan dapat berfungsi sebagai pengawas dan mencegah pihak manajemen perusahaan melakukan praktik penghindaran pajak. Hal ini didukung oleh hasil penelitian yang ditemukan oleh (Sandy \& Lukviarman, 2015). Dari pemaparan di atas maka dalam ditarik hipotesis pertama yaitu :

$\mathrm{H}_{1}$ : Persentasi dewan komisaris independen berpengaruh negatif terhadap dilakukannya penghindaran pajak

Teori keagenan menyatakan bahwa perusahaan besar memiliki biaya keagenan yang lebih besar daripada perusahaan kecil, (Company, Jensen, \& 
Meckling, 1976). Menurut (Siregar \& Siddharta Utama, 2005), semakin besar ukuran perusahaan biasanya informasi yang tersedia untuk investor dalam mengambil keputusan sehubungan dengan investasi saham yang ditanamkan dalam perusahaan tersebut semakin banyak. Oleh karena itu, kualitas laporan keuangan harus reliabel, terbebas dari manajemen laba karena dapat mengaburkan informasi yang tersedia. Laba yang besar akan menarik perhatian pemerintah untuk dikenakan pajak yang sesuai dengan peraturan perundang-undangan. Perusahaan berskala besar mempunyai lebih banyak sumber daya yang dapat digunakan untuk perencanaan pajak dan lobi politik (Noor, Fadzillah, \& Mastuki, 2010). Sehingga semakin besar ukuran perusahaan maka akan semakin baik manajemen pajaknya, karena semakin baik manajemen pajak perusahaan maka akan semakin rendah tarif pajak efektifnya, dari memaparan diatas maka dapat ditarik hipotesis sebagai berikut :

$\mathrm{H}_{2}$ : Ukuran perusahaan berpengaruh negatif terhadap dilakukannya penghindaran pajak

Profitabillitas merupakan suatu indikator kinerja manajemen dalam mengelola kekayaan perusahaan yang ditujukan oleh laba yang dihasilkan, (Sudarmadji \& Sularto, 2007). Rasio ini mengukur efektivitas manajemen secara keseluruhan yang ditujukan oleh besar kecilnya tingat keuntungan yang diperoleh dalam hubungannya dengan penjualan maupun investasi. Apabila rasio profitabilitas tinggi, berarti menunjukkan adanya efisiensi yang dilakukan oleh pihak manajemen. Laba yang meningkat mengakibatkan profitabilitas perusahaan juga meningkat. Penelitian ini mengambil Return On Asset (ROA) sebagai proksi profitabilitas. Analisis rasio ini sudah merupakan teknik analisa yang lazim 
digunakan oleh pimpinan perusahaan untuk mengukur efektivitas dari keseluruhan operasi perusahaan. Return On Asset (ROA) memberikan ukuran yang lebih baik atas profitabilitas perusahaan karena menunjukkan efektivitas manajemen dalam menggunakan asset untuk menghasilkan laba. Nilai Return On Asset (ROA) yang semakin tinggi maka akan memperlihatkan performa perusahaan yang semakin baik. Perusahaan dengan performa yang baik dan dapat menghasilkan laba diasumsikan tidak melakukan tax aviodance hal ini disebabkan perusahaan tersebut dapat mengatur pendapatan dan pembayaran pajaknya. Hal ini didukung oleh teori stakeholder dimana perusahaan sebagai entitas tidak hanya beroperasi guna untuk memperoleh keuntungan sendiri saja melainkan memberikan manfaat kepada seluruh stakeholder, dalam hal ini stakeholder yang dimaksud adalah pemerintah. Kelompok stakeholder inilah yang menjadi bahan pertimbangan bagi pihak manajemen untuk mengungkapkan informasi didalam laporan perusahaan. Argumen ini sesuai dengan hasil penelitian yang dilakukan oleh (Prakosa, 2014b) yang menemukan bahwa profitabilitas memiliki pengaruh negatif terhadap penghindaran pajak. Tingginya profitabilitas perusahaan akan berdampak pada dilakukan perencanaan pajak yang matang sehingga menghasilkan pajak yang optimal, sehingga kecenderungan melakukan penghindaran pajak akan menurun (Hanum \& Zulaikha, 2013). Sehingga dapat ditarik hipotesis sebagai berikut :

$\mathrm{H}_{3}$ : Return On Asset (ROA) berpengaruh negatif terhadap dilakukannya penghindaran pajak.

Sumber pendanaan operasional perusahaan tidak hanya berasal dari modal sendiri ataupun dari para pemegang saham saja akan tetapi juga dapat dimungkinan berasal dari hutang. Rasio ini mencerminkan kemampuan 
perusahaan dalam memenuhi seluruh kewajibannya yang ditunjukkan oleh modal sendiri yang digunakan sebagai pembayaran hutang. Semakin tinggi DER maka akan semakin tinggi dan besar pula resiko yang ditanggung oleh perusahaan serta rasio ini juga dapat memperlihatkan resiko tidak tertagihnya hutang perusahaan. Hutang yang dimiliki perusahaan akan menimbulkan beban tetap bagi perusahaan yaitu beban bunga. Semakin tinggi hutang perusahaan maka semakin tinggi beban bunga yang ditanggung oleh perusahaan, tingginya beban bunga oleh perusahaan akan dapat mengurangi laba yang diperoleh perusahaan. Manfaat yang dapat diambil oleh perusahaan dengan pengurangan laba tersebut adalah mengurangi beban pajak perusahaan, dapat diasumsikan semakin tinggi penggunaan utang semakin rendah beban pajak yang ditanggung oleh perusahaan. (Ozkan \& Ozkan, 2004) memberikan bukti bahwa perusahaan yang memiliki kewajiban pajak tinggi akan memilih untuk berutang agar mengurangi pajak. (Derashid \& Zhang, 2003) menjelaskan dalam penelitiannya bahwa hutang perusahaan berpengaruh negatif terhadap tarif pajak efektif yang menggambarkan bahwa hutang perusahaan dapat membantu mengurangi beban pajak perusahaan. Sehingga dapat ditarik hipotesis sebagai berikut :

$\mathrm{H}_{4}$ : Debt to Equity Ratio (DER) Berpengaruh negatif Terhadap Dilakukannya Penghindaran Pajak

\section{METODE PENELITIAN}

Jenis penelitian ini mengunakan pendekatan kuantitatif dengan bentuk asosiatif. Penelitian ini merupakan studi empiris yang dilakukan untuk membuktikan adanya pengaruh Komisaris Independen, Ukuran Perusahaan, Kinerja Keuangan 
ISSN: 2302-8556

E-Jurnal Akuntansi Universitas Udayana Vol.26.2.Februari (2019): 1601-1631

dan Leverage Terhadap Usaha Penghindaran Pajak. Dari uraian sebelumnya maka dapat digambarkan kerangka pemikiran teoritis dan model penelitian sebagai berikut :

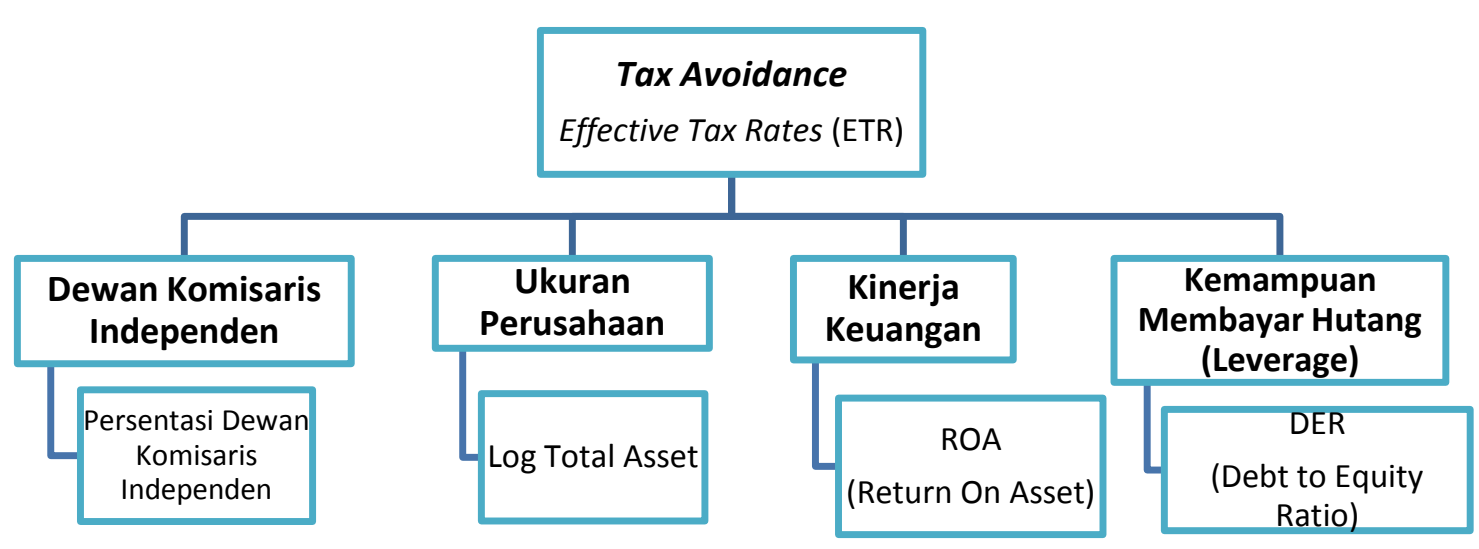

Sumber : Data Diolah, 2017

\section{Gambar 1. Kerangka Pemikiran Teoritis}

Sumber data dalam penelitian ini merupakan data sekunder yang merupakan sumber data penelitian yang diperoleh secara tidak langsung melalui media perantara.

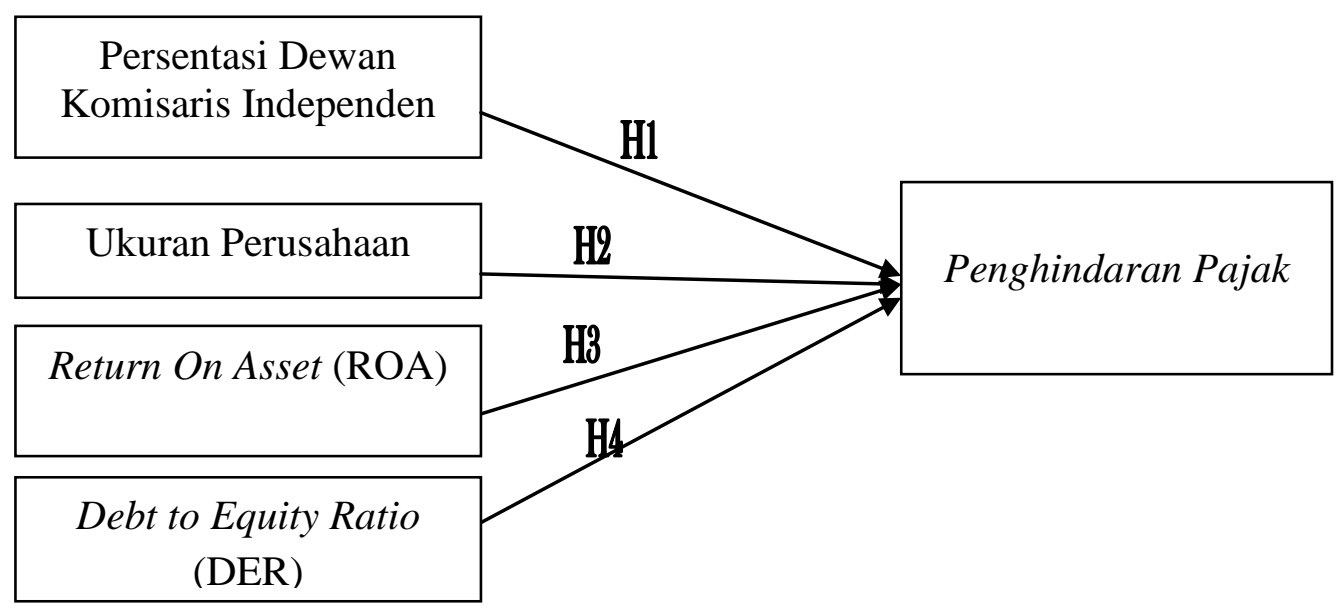

Sumber : Data Diolah, 2017

Variabel yang diteliti tersedia dengan lengkap dalam laporan tahunan, pelaporan keuangan dan ringkasan kinerja tahun 2013-2017. Untuk memperoleh data yang dibutuhkan dalam penelitian ini, penulis menggunakan teknik observasi 
dokumentasi dengan melihat laporan keuangan, laporan tahunan dan ringkasan kinerja perusahaan. Sumber data diperoleh dari website IDX : www.idx.co.id . Teknik pengambilan sampel penelitian ini dilakukan dengan menggunakan teknik purposive sampling yaitu melalui pengambilan sampel secara khusus berdasarkan kriteria-kriteria tertentu. Adapun kriteria yang digunakan untuk memilih sampel adalah sebagai berikut:

Tabel 1.

Hasil Pemilihan Sampel

\begin{tabular}{clc}
\hline No & \multicolumn{1}{c}{ Keterangan } & Jumlah \\
\hline Perusahaan manufaktur yang terdaftar di BEI tahun 2013-2017 & 145 \\
1 & Perusahaan yang delisted & $(15)$ \\
2 & Perusahaan yang new listing & $(14)$ \\
3 & Perusahaan yang data keuangannya tidak lengkap & $(24)$ \\
4 & Perusahaan yang laporan keuangannya dalam Dollar & $(21)$ \\
5 & Perusahaan memiliki laba negatif & $(30)$ \\
& Total perusahaan yanga memenuhi kreteria & 41 \\
\hline
\end{tabular}

Variabel dependen dalam penelitian ini adalah penghindaran pajak (tax avoidance). Pengukuran tax avoidance sendiri menggunakan proksi dengan menggunakan proksi Effective Tax Rates (ETR) yang diharapkan mampu mengidentifikasi keagresifan perencanaan pajak perusahaan yang dilakukan menggunakan perbedaan tetap maupun perbedaan temporer (Chen, Chen, Cheng, \& Shevlin, 2010) dengan rumus sebagai berikut:

$$
E T R=\frac{\text { Beban Pajak Penghasialan }}{\text { Pendapatan Sebelum Pajak }}
$$

Variabel independen dalam penelitian ini adalah Corporate governance yang diproyeksikan dengan Persentasi Dewan Komisaris Independen, ukuran perusahaan (logaritma Total Asset), kinerja perusahaan (Return On Asset) dan Leverage (Debt to Equity Ratio). 
Pengukuran komisaris independen ini dapat diperoleh dengan cara menjumlahkan komisaris independen kemudian dibagi dengan jumlah komisaris (Khurana dan Moser, 2009 dalam (Annisa \& Kurniasih, 2012). Komisaris independen didefinisikan sebagai seorang yang tidak terafiliasi dalam segala hal dengan pemegang saham pengendali, tidak memiliki hubungan afiliasi dengan direksi atau dewan komisaris serta tidak menjabat sebagai direktur pada suatu perusahaan yang terkait dengan perusahaan pemilik menurut peraturan yang dikelurkan oleh BEI, jumlah komisaris independen proporsional dengan jumlah saham yang dimiliki oleh pemegang saham yang tidak berperan sebagai pengendali dengan ketentuan jumlah komisaris independen sekurang-kurangnya tiga puluh persen (30persen) dari seluruh anggota komisaris, disamping hal itu komisaris independen memahami undang-undang dan peraturan tentang pasar modal serta diusulkan oleh pemegang saham yang bukan merupakan pemegang saham pengendali dalam Rapat Umum Pemegang Saham (Pohan, 2009). Pengukuran proporsi dewan komisaris indepen dapat dirumuskan sebagai berikut : Dewan Komisaris Independen $(D K I)=\frac{\text { Komisaris Independen }}{\text { Jumlah Komisaris }}$

Ukuran perusahaan dapat diukur dengan logaritma (log) dari jumlah asset. Proksi ini dipilih karena memiliki tingkat kesetabilan yang lebih dibandingkan proksi yang lain, dan proksi ini cendrung berkesinambungan antar periode (Hartono, 2013).

Return on Asset (ROA) merupakan salah satu rasio profitabilitas yang mengukur efektivitas perusahaan dalam menghasilkan keuntungan dengan memanfaatkan aktiva yang dimilikinya. Pemilihan ROA (Return on Asset) sebagai 
proksi kinerja keuangan dikarenakan ROA dapat merefleksikan keuntungan bisnis dan efisiensi perusahaan dalam pemanfaatan total aset (Kasmir, 2010). Rumus untuk menghitung ROA yaitu:

$R O A=\frac{\text { Laba bersih yang tersedia untuk pemegang saham biasa }}{\text { total asset }}$

Leverage merupakan suatu rasio keuangan yang menunjukan hubungan antara hutang perusahaan dengan modal yang dimiliki perusahaan. Pengukuran dalam rasio keuangan leverage ini adalah dengan menggunakan presentase terhadap total hutang dengan modal perusahaan yang disebut juga dengan Debt to Equity Ratio (DER). Semakin tinggi DER menunjukkan komposisi total hutang (jangka pendek dan jangka panjang) semakin besar dibanding dengan total modal sendiri, sehingga berdampak semakin besar beban perusahaan terhadap pihak luar. Meningkatnya beban terhadap kreditur menunjukkan sumber modal perusahaan sangat tergantung dengan pihak luar. Selain itu besarnnya beban hutang yang ditanggung perusahaan dapat mengurangi jumlah laba yang diterima perusahaan. Teknik analisis data yang digunakan dalam penelitian ini adalah analisis regresi linier berganda yang bertujuan untuk menganalisis hubungan linier antara 2 variabel independen atau lebih dengan 1 variabel dependen. Teknik analisis data ini mencakup Pengujian statistik desktiptif, uji asumsi klasik yang meliputi uji normalitas, uji multikolonieritas, uji autokorelasi, uji heteroskedastisitas serta uji hipotesa. Model regresi linier berganda tersebut adalah sebagai berikut :

$$
E T R=\alpha+\beta 1(D K I)+\beta 2(\text { Size })+\beta 3(R O A)+\beta 4(D E R)
$$




\section{HASIL DAN PEMBAHASAN}

Penelitian ini menggunakan seluruh perusahaan manufaktur yang terdaftar di Bursa Efek Indonesia (www.idx.co.id) sebagai objek penelitian dengan menggunakan motode purposive sampling sehingga dari 145 populasi penelitian diperoleh 41 perusahaan sebagai sampel penelitian. Sebelum melakukan pengujian hipotesis, terlebih dahulu diuraikan gambaran sebaran nilai dari masing-masing variabel. Selanjutnya deskripsi dari masing-masing variabel dijelaskan pada tabel dibawah ini:

Tabel 2.

Descriptive Statistics

\begin{tabular}{lccccc}
\hline Keterangan & N & Minimum & Maximum & Mean & $\begin{array}{c}\text { Std. } \\
\text { Deviation }\end{array}$ \\
\hline ETR & 205 &, 004 & 2,05 &, 2955 &, 17896 \\
DKI & 205 & 20,00 & 100,00 & 41,3479 & 12,70856 \\
Log_Asset & 205 & 11,13 & 14,47 & 12,5405 &, 72692 \\
ROA & 205 & $-9,71$ & 71,51 & 10,1076 & 10,46284 \\
DER & 205 &, 05 & 6,56 &, 9676 &, 96439 \\
Valid N (listwise) & 205 & & & & \\
\hline Sumber : Data diolah, 2017 & & & &
\end{tabular}

Hasil tabel 2 menunjukkan statistik deskriptif masing-masing variabel penelitian. Hasil Statisktik deskriptif menunjukkan bahwa Penghindaran Pajak (Tax Avoidance) yang diukur menggunakan Efective Tax Ratio (ETR) memiliki nilai rata-rata sebesar 0,2955, untuk nilai maksimum ETR sebesar sebesar 2,05 dimiliki oleh PT.Trias Sentosa Tbk pada tahun 2017. Sementara nilai ETR yang terendah dimiliki oleh PT.Ultrajaya Milk Industry and Trading Company Tbk pada tahun 2017 sebesar 0,004, dan ETR memiliki standar deviasi sebesar 0,17896. Penelitian ini mengukur Good corporate governance dengan Proporsi Dewan Komisaris Independen yang memiliki nilai rata-rata sebesar 41,3479 persen hal ini menunjukkan bahwa secara rata-rata perusahaan manufaktur yang 
terdaftar di Bursa Efek Indonesia dalam kurun waktu 2013-2017 telah memiliki lebih dari 30persen proporsi Dewan Komisaris Independen. Nilai Proporsi Dewan Komisaris Independen tertinggi dimiliki oleh PT. Arwana Citra Mulia Tbk dari tahun 2013-2015 sebesar 100 persen sementara untuk nilai terendah PT. Hanjaya Mandala Sampoerna Tbk pada tahun 2017 sebesar 20 persen , persentasi ini dibawah persentasi Dewan Komisaris Independen yang telah ditetapkan oleh OJK yaitu sebesar 30 persen, sementara nilai standar deviasi Dewan Komisaris Independen 12,70856. Logaritma Total Asset dipilih sebagai proksi ukuran perusahaan dalam penelitian ini, tabel 2 memperlihatkan bahwa nilai rata-rata Logaritma Total Asset sebesar 12,5405 dan standar deviasi 0,72692 . Nilai maximum dari Logaritma Total Asset sebsar 14,47 hal ini setara dengan Rp 295.646.000.000.000 ditunjukkan oleh PT. Astra International Tbk tahun 2017. Sementara nilai Logaritma Total Asset minimal dimiliki oleh PT. Lionmesh Prima Tbk pada tahun 2015 dengan nilai total asset sebesar $\mathrm{Rp}$ 133.782.751.041. Variabel selanjutnya adalah kinerja keuangan yang diukur menggunakan Return On Asset (ROA) yang miliki standar deviasi 10,46284 dan nilai rata-rata sebesar 10,1076. Nilai Return On Asset (ROA) minimal sebesar -9,71 dimiliki oleh PT.Tiga Pilar Sejahtera Food Tbk pada tahun 2017 sementara nilai maximum dari Return On Asset (ROA) 71,51 dimiliki oleh PT. Unilever Indonesia Tbk pada tahun 2013. Variabel terakhir pada tabel 2 menunjukkan nilai Debt Equity Ratio (DER) yang digunakan sebagai proksi kemampuan perusahaan melunasi hutang (leverage) pada penelitian ini memiliki nilai rata-rata sebesar 0,9676 dan standar deviasi 0,96439. Nilai tertinggi Debt Equity Ratio (DER) 6,56 yang dimiliki oleh 
PT. Jembo Cable Company Tbk pada tahun 2013 dan nilai terendah 0,05 yang ditunjukkan oleh PT Kalbe Farma Tbk tahun 2013.

Sebelum melakukan analisis regresi maka perlu dilakukan uji asumsi klasik untuk menguji modal regresi yang digunakan yang terdiri dari uji normalitas, uji multikolinieritas, uji autokorelasi, uji heteroskedastisitas.

Tabel 3.

Hasil Uji Asumsi Klasik

\begin{tabular}{|c|c|c|c|c|c|c|}
\hline \multirow{2}{*}{\multicolumn{2}{|c|}{$\begin{array}{l}\text { Parameter } \\
\text { Yang Diuji }\end{array}$}} & \multirow{2}{*}{$\begin{array}{c}\text { Uji } \\
\text { Normalitas } \\
\text { Asymp Sig } \\
\text { (2-tailed) } \\
\end{array}$} & \multicolumn{2}{|c|}{$\begin{array}{c}\text { Uji } \\
\text { Multikolonieritas }\end{array}$} & \multirow{2}{*}{$\begin{array}{c}\text { Uji } \\
\text { Autokorelasi } \\
\text { DW }\end{array}$} & \multirow{2}{*}{$\begin{array}{c}\text { Uji } \\
\text { Heteroskedastisitas } \\
\text { Sig }\end{array}$} \\
\hline & & & Tolerance & VIF & & \\
\hline \multicolumn{7}{|l|}{ Residual } \\
\hline DKI & (X1) & & 0,811 & 1,233 & & 0,145 \\
\hline Log_Asset & $(\mathrm{X} 2)$ & & 0,976 & 1,024 & & 0,052 \\
\hline ROA & (X3) & & 0,881 & 1,134 & & 0,847 \\
\hline DER & $(\mathrm{X} 4)$ & & 0,880 & 1,136 & & 0,168 \\
\hline \multicolumn{3}{|c|}{ Durbin_Witson } & & & 2,078 & \\
\hline
\end{tabular}

Sumber : Data diolah, 2017

Uji Normalitas bertujuan untuk menguji normalitas dalam penelitian ini dengan menggunakan uji Kolmogorov Smirnov, dengan uji ini dapat diketahui data yang digunakan terdistribusi normal atau tidak. Dasar pengambilan keputusan adalah jika nilai signifikansinya /Asymp. Sig. (2-tailed) diatas 5persen maka model regresi memenuhi asumsi normalitas. Penelitian ini memiliki nilai Asymp. Sig. (2-tailed) sebesar 0,200 maka dapat dikatakan bahwa data dalam penelitian ini terdistribusi dengan normal.

Uji Multikolonieritas bertujuan untuk menguji suatu model regresi ditemukan adanya kolerasi antar variabel bebas. Cara untuk mengetahui terjadi multikolonieritas atau tidak yaitu dengan melihat nilai Tolerance dan variance Inflation Factor (VIF). Nilai cut off yang umum dipakai untuk menunjukkan adanya multikolinearitas adalah nilai Tolerance $<0,10$ atau sama dengan nilai VIF 
> 10 (Ghozali, 2013). Tabel 3 menunjukkan dari setiap variabel yang diteliti memiliki nilai Tolerance $<0,10$ dan nilai VIF $>10$ maka dapat disimpulkan bahwa tidak terjadi multikolinieritas antara seluruh variabel bebas dan menggambarka multikolinieritas terpenuhi.

Uji autokorelasi bertujuan menguji apakah dalam model regresi linear ada korelasi antara kesalahan pengganggu pada periode $\mathrm{t}$ dengan kesalahan pengganggu pada periode sebelumnya t-1 (Ghozali, 2013). Autokorelasi muncul karena observasi yang berurutan sepanjang tahun yang berkaitan satu dengan yang lainnya. Hal ini sering ditemukan pada time series. Untuk mengetahui adanya autokorelasi dilakukan dengan uji Durbin Watson dan membandingkannya dengan nilai dl dan du yang terdapat pada tabel. Hasil uji autokorelasi pada peneltian ini memiliki nilai DW sebesar 2,078 lebih besar dari batas atas (du) 1,80942 dan kurang dari $(4-1,80942=2,19058)$ maka dapat disimpuka bahwa tidak terdapat autokorelasi.

Uji heteroskedastisitas bertujuan untuk menguji model regresi terjadi ketidaksamaan variance dari residual satu pengamatan ke pengamatan yang lain. Cara untuk mengetahui apakah terjadi heteroskedastisitas atau tidak yaitu dengan melakukan pengujian heteroskedastisitas menggunakan teknik uji koefisien korelasi Spearman's rho yaitu mengorelasikan variabel independen dengan residualnya. Pengujian menggunakan tingkat signifikansi 0,05 dengan uji 2 sisi. Jika kolerasi antar variabel independen dengan residual memberikan signifikansi lebih dari 0,05 maka dapat dikatakan bahwa tidak terjadi problem 
heteroskedastisitas (Priyatno, 2009). Hasil uji heteroskedastisitas menunjukkan untuk seluruh variabel memiliki nilai signifikansi lebih dari 0,05.

Penelitian ini menggunakan analisis regresi linier berganda sebagai alat analisis data untuk menguji pengaruh Peran Komisaris Independen, Ukuran Perusahaan, Kinerja Keuangan dan Kemampuan Perusahaan Dalam Membayar Hutang Terhadap Usaha Penghindaran Pajak, dengan model regresi linier berganda tersebut adalah sebagai berikut :

$$
E T R=\propto+\beta 1(D K I)+\beta 2(\text { Size })+\beta 3(R O A)+\beta 4(D E R)
$$

Tabel 4.

Hasil Uji Hipotesis

\begin{tabular}{lccccc}
\hline \multicolumn{1}{c}{ Model } & \multicolumn{2}{c}{$\begin{array}{c}\text { Unstandardized } \\
\text { Coefficients }\end{array}$} & $\begin{array}{c}\text { Standardized } \\
\text { Coefficients }\end{array}$ & t & Sig. \\
\cline { 2 - 4 } & $\mathrm{B}$ & $\begin{array}{c}\text { Std. } \\
\text { Error }\end{array}$ & Beta & & \\
\cline { 2 - 4 } (Constant) & 0,816 & 0,210 & & 3,879 & 0,000 \\
DKI & 0,001 & 0,001 & 0,069 & 0,924 & 0,357 \\
Log_Asset & $-0,043$ & 0,017 & $-0,173$ & $-2,552$ & 0,011 \\
ROA & $-0,004$ & 0,001 & $-0,239$ & $-3,349$ & 0,001 \\
DER & 0,015 & 0,013 & 0,080 & 1,121 & 0,264 \\
R & 0,324 & & & & \\
R Square & 0,105 & & & & \\
Adjusted R Square & 0,687 & & & &
\end{tabular}

Hasil perhitungan model regresi pertama dengan program SPSS for windows versi 22.00 diperoleh nilai Adjusted $\mathrm{R}$ Square $=0,687$. Hal ini berarti bahwa Tax Avoidance yang diproksikan dengan ETR (Effective Tax Rate) dapat dijelaskan oleh variabel independen sebesar 68,7persen sedangkan sisanya sebesar 31.3persen dipengaruhi oleh variabel lain yang tidak diteliti.

Hasil pengujian hipotesis pertama (H1) untuk mengetahui apakah variabel independen berpengaruh terhadap variabel dependen, maka dilakukan pengujian dengan menggunakan uji $\mathrm{t}(t$ test). Uji t digunakan untuk menguji signifikansi 
konstanta dan setiap variabel independennya. Dari tabel 4 regresi diatas dapat dilihat besarnya $\mathrm{t}_{\text {hitung }}$ dari hasil perhitungan model regresi pada variabel Dewan Komisaris Independen 0,924 lebih kecil dari 1.65251 atau $t_{\text {hitung }}<t_{\text {tabel }}(0,924<$ 1.65251) maka Ho diterima dan HA ditolak, berarti tidak ada pengaruh yang signifikan antara Proporsi Dewan Komisaris Independen terhadap Tax Avoidance dan ini terlihat dari nilai sig $=0,357>0,05$ maka hal ini berarti bahwa Proporsi Dewan Komisaris Independen tidak berpengaruh terhadap tax avoidance. Dewan Komisaris Independen sebagai implementasi penerapan Good Corporate Governance memiliki peran sebagai pengawas dan wakil dari investor serta menetukan kebijakan strategis jangka panjang dan pendek tanpa melanggar aturan hukum yang berlaku termasuk menentukan kebijakan pajak. Hasil penelitian ini menunjukkan bahwa Proporsi Dewan Komisaris Independen tidak berpengaruh terhadap dilakukannya tindakan penghindaran pajak (tax avoidance). Rasionalisasi untuk hasil penelitian ini adalah komisaris independen diperusahaan publik sebagai pelengkap untuk sekedar memenuhi regulasi yang berlaku, dalam hal ini komisaris independen tidak melaksanakan tugas secara efektif dalam melindungi perusahaan publik sehingga kebedaraan dewan komisaris hanya sebagai simbol semata. Hasil penelitian ini sejalan dengan hasil penelitian yang ditemukan oleh (Hanum \& Zulaikha, 2013). Hal ini disebabkan karena dewan komisaris independen merupakan bagian dari dewan komisaris perseroan tidak melakukan fungsi pengawasan yang cukup baik terhadap manajemen perusahaan. Kurangnya pengetahuan mengenai latar belakang kegiatan bisnis perusahaan dapat mempengaruhi kinerja pengawasan komisaris independen terhadap 
manajemen perusahaan dan mengakibatkan gagalnya perumusan strategi perusahaan yang efektif termasuk dalam strategi yang berhubungan dengan pajak. Namun hasil penelitian ini bertentangang dengan hasil penelitian yang ditemukan oleh (Sandy \& Lukviarman, 2015).

Hasil pengujian hipotesis kedua $(\mathrm{H} 2)$ dapat dilihat dari tabel 4 regresi diatas. Dapat dilihat besarnya $\mathrm{t}$ hitung dari hasil perhitungan model regresi pada variabel Ukuran Perusahaan (Size) yang diukur menggunakan Logaritma Total Asset sebesar -2,552 lebih kecil dari 1.65251 atau $t_{\text {hitung }}<t_{\text {tabel }}(-2,552<1.65251)$ dengan nilai sig=0,011 $<0,05$ maka hipotesis 2 diterima, hal ini berarti secara parsial ukuran perusahaan berpengaruh negatif terhadap dilakukannya tindakan tax avoidance. Penelitian ini mengklasifikasikan ukuran perusahaan berdasarkan jumlah total asset yang dimiliki oleh perusahaan. Ukuran perusahaan mempengaruhi cara perusahaan untuk memenuhi kewajiban perpajakannya sebagai wajib pajak, selain itu ukuran perusahaan juga menjadi faktor perusahaan terjadinya tax avoidance (penghindaran pajak). Penelitian ini menemukan bahwa ukuran perusahaan memiliki pengaruh negatif terhadap dilakukannya tindakan penghindaran pajak (tax avoidance), adapun raionalisasi untuk hasil penelitian ini bahwa perusahaan dengan ukuran yang besar akan menjadi sorotan oleh pemerintah (regulator) sehingga perusahaan besar menggunakan sumber dayanya untuk melakukan perencanaan pajak yang baik dan menataati aturan perpajakan yang berlaku. Hasil penelitian ini sejalan dengan penelitian yang dilakukan oleh (Kurniasih \& Sari, 2013), namun hasil yang berbeda ditemukan oleh penelitian (Putri \& Putra, 2017). 
Hasil pengujian hipotesis ketiga (H3) dapat dilihat dari tabel 4 diatas dapat dilihat hasil uji hipotesis yang ketiga. Dapat dilihat besarnya $t$ hitung dari hasil perhitungan model regresi pada variabel Return On Asset (ROA) adalah sebesar 3,349 lebih kecil dari 1.65251 atau $\mathrm{t}_{\text {hitung }}<\mathrm{t}_{\text {tabel }}(-3,349<1.65251)$ dengan nilai $\operatorname{sig}=0,001<0,05$ maka hipotesis 3 diterima hal ini berarti secara parsial Return On Asset (ROA) berpengaruh negatif terhadap dilakukannya tindakan tax avoidance. Return On Asset (ROA) merupakan salah satu rasio yang menjadi indikator untuk menilai perubahan potensi sumber daya ekonomi dimasa depan, dengan prosek yang baik dimasa depan akan menarik investor untuk berinvestasi. Rasio Return On Asset (ROA) menunjukkan kinerja manajemen dalam mengelola kekayaan perusahaan untuk menghasilkan laba, tidak hanya itu rasio ini memiliki keunggulan sebagai alat kontrol dan perencanaan dalam pengambilan keputusan. Pada perusahaan yang telah menjalankan praktek akuntansi yang baik Rasio Return On Asset dapat mengukur efesiensi penggunaan modal, efesiensi penjualan dan efesiensi produksi. Semakin tinggi laba yang diperoleh perusahaan maka akan semakin besar beban pajak yang harus dibayar oleh perusahaan ke kas negara. Hasil penelitian ini menunjukkan bahwa Return On Asset (ROA) berpengaruh negatif terhadap dilakukannya tindakan tax avoidance dengan rasionalisasi bahwa perusahaan yang memiliki nilai Return On Asset (ROA) yang tinggi akan menunjukkan kinerja manajemen yang baik dalam menghasilkan laba . Perusahaan dengan profitabilitas tinggi memiliki kesempatan untuk memposisikan untuk melakukan tax planning yang dapat mengurangi jumlah beban kewajiban perpajakan (Chen et al., 2010). Dengan perencanaan pajak yang baik maka akan 
ISSN: 2302-8556

E-Jurnal Akuntansi Universitas Udayana Vol.26.2.Februari (2019): 1601-1631

memperoleh pajak yang optimal, hal tersebut berakibat kecenderungan perusahaan untuk melakukan penghindaran pajak akan menurun (Prakosa, 2014a). Hasil penelitian ini sejalan dengan hasil penelitian yang ditemukan oleh (Kurniasih \& Sari, 2013). Namun hasil yang berbeda ditemukan oleh penelitian yang dilakukan oleh (Dewi \& Noviari, 2017).

Hasil pengujian hipotesis keempat (H4) dapat terlihat tabel 4 regresi diatas dapat dilihat besarnya $\mathrm{t}$ hitung dari hasil perhitungan model regresi pada variabel Debt to Equity Ratio (DER) 1,121 lebih kecil dari 1.65251 atau $\mathrm{t}_{\text {hitung }}<\mathrm{t}$ tabel $(1,121<1.65251)$ maka Ho diterima dan HA ditolak, berarti tidak ada pengaruh yang signifikan antara Debt to Equity Ratio (DER) terhadap Tax Avoidance dan ini terlihat dari nilai sig $=0,264>0,05$ maka hal ini berarti bahwa Debt to Equity Ratio (DER) tidak berpengaruh terhadap tax avoidance. Leverage merupakan salah satu rasio keuangan yang menggambarkan hubungan antara hutang perusahaan terhadap modal maupun asset perusahaan, dimana rasio ini menunjukkan risiko yang dihadapi perusahaan. Rasio ini juga melihat sejauh mana perusahaan dibiayai oleh hutang atau pihak luar dengan kemampuan perusahaan yang digambarkan oleh modal. Penelitian ini menggunakan Debt to Equity Ratio (DER) sebagai alat pengukuran Leverage, hal ini disebabkan Debt to Equity Ratio (DER) memberikan gambaran terhadap nilai hutang yang dimiliki oleh perusahaan, dengan semakin besar nilai Debt to Equity Ratio (DER) maka resiko operasional dibandingkan dengan nilai ekuitas yang dimiliki perusahaan akan semakin tinggi pula begitu juga sebaliknya. Hasil penelitian ini menemukan bahwa Debt to Equity Ratio (DER) tidak memiliki pengaruh yang signifikan 
terhadap tindakan penghindaran pajak (tax avoidance). Hal ini mengindikasikan bahwa keputusan pendanaan yang dilakukan oleh perusahaan baik internal dan eksternal akan menghasilkan beban bunga dapat menjadi pengurang laba pajak, sedangkan biaya bunga pinjaman bank tidak diperbolehkan sebagai beban pengurang penghasilan kena pajak sesuai dengan Surat Edaran Direktorat Jenderal Pajak Nomor 46/PJ.4/1995. Oleh karena itu kebijakan stuktur pendanaan melalui hutang tidak dapat menjadi gambaran bagi perusahaan melakukan praktik penghindaran pajak hal ini disebabkankan adanya aturan yang mengikat perusahaan membayarkan pajak seharusnya. Hal ini sesuai dengan penelitian yang dilakukan oleh (Munandar, Nazar, \& Khairunnisa, 2016). Hasil yang sama ditemukan oleh (Arianandini \& Ramantha, 2018) yang membuktikan bahwa leverage tidak berpengaruh secara signifikan terhadap tindakan penghindaran pajak hal ini disebabkan perusahaan dengan tingkat leverage yang tinggi memiliki akan memiliki beban bunga dan resiko yang tinggi pula, sehingga jika perusahaan banyak menggunakan hutang dari pihak luar perusahaan dapat menjadikan laba perusahaan menjadi tidak optimal. Tapi hasil yang berbeda ditemukan oleh hasil penelitian yang dilakukan oleh (Putri \& Putra, 2017).

\section{SIMPULAN}

Penelitian ini bertujuan untuk memberikan bukti empiris mengenai pengaruh Komisaris Independen, Ukuran Perusahaan, Kinerja Keuangan dan Leverage Terhadap Usaha Penghindaran Pajak. Dan dari pembahasan hasil penelitian sebelumnya maka dapat ditarik kesimpulan bahwa komisaris independen sebagai 
pengawas belum melakukan tugas secara optimal dan efektif sehingga mengakibatkan gagalnya pihak komisaris independen sebagai pencegah terjadinya penghindaran pajak yang dilakukan oleh pihak manajemen perusahaan sehingga perumusan strategi perusahaan yang efektif termasuk dalam strategi yang berhubungan dengan manajemen pajak yang tidak optimal. Tidak hanya itu penelitian ini membuktikan bahwa Debt to Equity Ratio (DER) sebagai keputusan pendanaan yang dilakukan oleh perusahaan baik internal dan eksternal akan menghasilkan beban bunga dapat menjadi pengurang laba kena pajak. Sedangkan biaya bunga pinjaman bank tidak diperbolehkan sebagai beban pengurang penghasilan kena pajak sesuai dengan Surat Edaran Direktorat Jenderal Pajak Nomor 46/PJ.4/1995 sehingga hal ini menjadikan perusahaan lebih mematuhi aturan perundang-undangan yang berlaku dan membayar pajak mereka sesuai yang sebenarnya. Ukuran perusahaan yang besar akan menjadi daya tarik tersendiri bagi pemerintah (regulator) sehingga besar cendrung tidak melakukan praktik penghindaran pajak dengan melakukan mengelolaan dan menggunakan sumber dayanya untuk melakukan perencanaan pajak yang baik dan menataati aturan perpajakan yang berlaku. Perusahaan dengan nilai Return On Asset (ROA) yang tinggi akan menunjukkan kinerja manajemen yang baik dalam menghasilkan laba sehingga memotivasi perusahaan untuk melakukan perencanaan pajak yang baik dan dapat memperoleh pajak yang optimal sehingga penghindaran pajak akan menurun. Saran yang dapat diberikan adalah hendaknya Pemerintah khususnya Direktorat Jenderal Pajak selaku regulator menyempurnakan aturan perundang-undangan sehingga para pelaku bisnis tidak 
dapat memanfaatkan loopholes untuk melakukan praktik penghindaran pajak. Dan bagi dewan komisaris agar melaksanakan fungsinya sebagai pengawas dengan baik dan efektif sehingga dapat melakukan tindakan pencegahan terhadap perusahaan yang melakukan penghindaran pajak.

\section{REFERENSI}

Annisa, N. A., \& Kurniasih, L. (2012). Pengaruh Corporate Governance Terhadap Tax Avoidance. Jurnal Akuntansi Dan Auditing. https://doi.org/10.1017/CBO9781107415324.004.

Arianandini, P. W., \& Ramantha, I. W. (2018). Pengaruh Profitabilitas, Leverage, dan Kepemilikan Institusional pada Tax Avoidance. Udayana, E-Jurnal Akuntansi Universitas, 22(No 3), 2088-2116. https://doi.org/10.24843/EJA.2018.v22.i03.p17.

BPS. (2018). Realisasi Penerimaan Negara (milyar rupiah), 2007-2018. BPS. Retrieved from https://www.bps.go.id/statictable/2009/02/24/1286/realisasipenerimaan-negara--milyar-rupiah---2007-2018.html.

Chen, S., Chen, X., Cheng, Q., \& Shevlin, T. (2010). Are family firms more tax aggressive than non-family firms? Journal of Financial Economics, 95(1), 41-61. https://doi.org/10.1016/j.jfineco.2009.02.003.

Company, P., Jensen, C., \& Meckling, H. (1976). Theory Of The Firm: Managerial Behavior, Agency Costs And Ownership Structure, 3, 305-360.

Derashid, C., \& Zhang, H. (2003). Effective tax rates and the "industrial policy" hypothesis: Evidence from Malaysia. Journal of International Accounting, Auditing and Taxation. https://doi.org/10.1016/S1061-9518(03)00003-X.

Dewi, N. L. P. P., \& Noviari, N. (2017). Pengaruh Ukuran Perusahaan, Leverage, Profitabilitas dan Corporate Social Responsibility Terhadap Penghindaran Pajak (Tax Avoidance). E-Jurnal Akuntansi Universitas Udayanaa, 21(1), 830-859.

Efffendi, M. A. (2016). The Power of Good Corporate Governance Teori dan Implementasi. (D. A. Halim, Ed.) (2nd ed.). Jakarta: Salemba Empat.

Fernández-Rodríguez, E., \& Martínez-Arias, A. (2012). Do Business Characteristics Determine an Effective Tax Rate? Chinese Economy, 45(6), 60-83. https://doi.org/10.2753/CES1097-1475450604. 
Ghozali, I. (2013). Aplikasi Analisis Multivariate dengan Program IBM SPPS 21. (P. P. Harto, Ed.) (7th ed.). Semarang: Badan Penerbit Universitas Diponegoro.

Ginting, S. (2016). Pengaruh Corporate Governance dan Kompensasi Rugi Fiskal Terhadap Penghindaran Pajak dengan Ukuran Perusahaan Sebagai Variabel Moderating. Jurnal Wira Ekonomi Mikroskil, 6, 1-12.

Hanum, H. R., \& Zulaikha. (2013). Pengaruh Karakteristik Corporate Governance Terhadap Effective Tax Rate (Studi Empiris pada BUMN yang Terdaftar di BEI 2009-2011). Diponegoro, 2 (2)(Semarang: Universitas Diponegoro), 110.

Hartono, J. (2013). Teori Portofolio dan Analisis Investasi (8th ed.). Yogyakarta: BPFE-Yogyakarta.

Kasmir. (2010). Pengantar Manajemen Keuangan (Edisi satu). Jakarta: Kencana Prenada Media Group.

Kurniasih, T., \& Sari, M. M. R. (2013). Pengaruh Return on Assets , Leverage , Corporate Governance, Ukuran Perusahaan Dan Kompensasi Rugi Fiskal Pada Tax Avoidance (The Effect of Return on Asset, Leverage, Corporate Governance, Company Size, and Fiscal Loss Compensation in Tax Avoidance). Buletin Studi Ekonomi, 18(1), 58-66.

Lukviarman, N. (2016). Corporate Governance.pdf. (R. N. Hamidawati, Ed.), Blackwell Handbook of Strategic Management. Solo: PT. Era Adicitra Intermedia.

Munandar, R. T., Nazar, M. R., \& Khairunnisa. (2016). Pengaruh Ukuran Perusahaan, Leverage, Dan Kompensasi Rugi Fiskal Terhadap Tax Avoidance. E-Proceeding of Management ISSN:2355-9357, 3(3), 34173424 .

Mustami, A. A. (2014, June 13). Coca-Cola Diduga Akali Setoran Pajak. Kompas.Com. Retrieved from https://ekonomi.kompas.com/read/2014/06/13/1135319/CocaCola.Diduga.Akali.Setoran.Pajak

Noor, R. M., Fadzillah, N. S. M., \& Mastuki, N. A. (2010). Corporate Tax Planning: A Study On Corporate Effective Tax Rates of Malaysian Listed Companies. International Journal of Trade, Economics and Finance, 1(2), 189-193. https://doi.org/10.7763/IJTEF.2010.V1.34 
Nugraha, M. C. J., \& Putu Ery Setiawan. (2019). Pengaruh Penghindaran Pajak (Tax Avoidance) Pada Nilai Perusahaan Dengan Transparansi Sebagai Variabel Pemoderasi. E-Jurnal Akuntansi Universitas Udayana, 26(1), 398425. https://doi.org/10.24843/EJA.2019.v26.i01.p15

Ozkan, A., \& Ozkan, N. (2004). Corporate cash holdings: An empirical investigation of UK companies. Journal of Banking and Finance, 28(9), 2103-2134. https://doi.org/10.1016/j.jbankfin.2003.08.003

Pohan, H. T. (2009). Analisis Pengaruh Kepemilikan Institusi, Rasio Tobin Q, Akrual Pilihan, Tarif Efektif Pajak, dan Biaya Pajak Ditunda terhadap Penghindaran Pajak Pada Perusahaan Publik. Jurnal Informasi, Perpajakan, Akuntansi Dan Keuangan Publik, 4(2), 113-135.

Prakosa, K. B. (2014a). Pengaruh Profitabilitas, Kepemilikan Keluarga dan Corporate Governance Terhadap Penghindaran Pajak Di Indonesia. SNA 17 Mataram, Lombok Universitas Mataram 24-27 Sept 2014, 1-27.

Prakosa, K. B. (2014b). Pengaruh Profitabilitas, Kepemilikan Keluarga dan Corporate Governance Terhadap Penghindaran Pajak Di Indonesia. SNA 17 Mataram, Lombok Universitas Mataram 24-27 Sept 2014, 1-27.

Priyatno, D. (2009). 5 Jam Belajar Olah Data Dengan SPSS 17.pdf. (J. Widiyatmoko, Ed.). Yogyakarta: Andi Yogyakarta.

Puspita, D., \& Febrianti, M. (2010). Faktor-Faktor Yang Memengaruhi Penghindaran Pajak Pada perusahaan Manufaktur di BEI. Jurnal Bisnis Dan Akuntansi, 19(1), 1.

Putri, V. R., \& Putra, B. I. (2017). Pengaruh Leverage, Profitability, Ukuran Perusahaan dan Proporsi Kepemilikan Institusional Terhadap Tax Avoidance. Jurnal Ekonomi Manajemen Sumber Daya, 19(1), 1-11.

Raharjo, S. A., \& Daljono. (2014). Pengaruh Ukuran Dewan Komisaris, Direksi, Komisaris Independen, Struktur Kepemilikan, Dan Indeks Corporate Governance Terhadap Asimetri Informasi, 3(3), 1-13.

Rusydi, M. K. (2013). Pengaruh Ukuran Perusahaan Terhadap Aggressive Tax Avoidance Di Indonesia. Jurnal Akuntansi Multiparadigma, 4(2), 322-329.

Sandy, S., \& Lukviarman, N. (2015). Pengaruh Corporate Governance terhadap Tax Avoidance: Studi Empiris pada Perusahaan Manufaktur. Jurnal Akuntansi \& Auditing Indonesia, 19, 85-98. https://doi.org/10.1017/CBO9781107415324.004 
Sartori, N. (2008). Effects Of Strategic Tax Behaviors On Corporate Governance. SSRN Electronic Journal. Retrieved from http://ssrn.com/abstract=1358930

Siregar, S. V. N. ., \& Siddharta Utama, C. (2005). Pengaruh Struktur Kepemilikan, Ukuran Perusahaan, Dan Praktek Corporate Governance Terhadap Pengelolaan Laba (Earnings Management). Simposium Nasional Akuntansi XVI Solo, (September), 15-16.

Suandy, E. (2014). Hukum Pajak.pdf. (E. S. Suharsi, Ed.) (6th ed.). Jakarta: Salemba Empat.

Sudarmadji, A. M., \& Sularto, L. (2007). Pengaruh Ukuran Perusahaan, Profitabilitas, Leverage, dan Tipe Kepemilikan Perusahaan Terhadap Luas Voluntary Disclosure Laporan Keuangan Tahunan. Proceeding PESAT(Psikologi, Ekonomi, Sastra, Arsitek \& Sipil) Auditorium Kampus Gunadarma,. https://doi.org/10.1049/ip-f-1.1985.0021

Waluyo, T. M., Basri, Y. M., \& Riau. (2015). Pengaruh Return on Asset , Leverage, Ukuran Perusahaan , Kompensasi Rugi Fiskal dan Kepemilikan Institusi Terhadap Penghindaran Pajak. Simposium Nasional Akuntansi XVIII, 4, 1-25. 